\title{
Blockade of TRPM8 activity reduces the invasion potential of oral squamous carcinoma cell lines
}

\author{
YOSHIHIKO OKAMOTO $^{1}$, TSUYAKO OHKUBO ${ }^{2}$, TETSURO IKEBE $^{1}$ and JUN YAMAZAKI ${ }^{2}$ \\ Departments of ${ }^{1}$ Oral and Maxillofacial Surgery and ${ }^{2}$ Physiological Science and Molecular Biology, \\ Fukuoka Dental College, 2-15-1 Tamura, Sawara-ku, Fukuoka 814-0193, Japan
}

Received November 11, 2011; Accepted December 16, 2011

DOI: $10.3892 /$ ijo.2012.1340

\begin{abstract}
Several members of the transient receptor potential (TRP)-channel family are expressed in cancer cells. One, cold/ menthol-sensitive TRPM8, is reportedly an important player in carcinogenesis in human prostate cancer, although its involvement in oral squamous cell carcinoma (SCC) remains unclear. The present immunohistochemistry and RT-PCR results revealed intense TRPM8 expression in two SCC cell lines, HSC3 and HSC4, derived from the human tongue. Menthol, icilin, and a more specific TRPM8 agonist (WS-12) induced non-specific cation currents, with $\mathrm{Ca}^{2+}$ permeability being greater than that of $\mathrm{Na}^{+}$or $\mathrm{K}^{+}$. The novel TRPM8 antagonist RQ-00203078 (RQ) profoundly reduced such agonist-induced cation currents. Intracellular $\mathrm{Ca}^{2+}$ imaging revealed that menthol induced both intracellular $\mathrm{Ca}^{2+}$ release and store-operated $\mathrm{Ca}^{2+}$ entry, with RQ inhibiting each effect. To assess the possible pathophysiological role of TRPM8 in oral SCC, we performed motility and invasion assays, and gelatin zymography. Menthol augmented the migration and invasion abilities of both HSC3 and HSC4 cells by potentiating MMP-9 activity. RQ suppressed all of these effects. These results may aid understanding of the pathophysiological implications of TRPM8 channels in the oral SCC cells, support TRP proteins as valuable targets for pharmaceutical intervention, and inform the targeting of oral $\mathrm{SCC}$ in which the prognosis is poor.
\end{abstract}

\section{Introduction}

Squamous cell carcinoma (SCC) is the most frequent cancer in the oral and maxillofacial regions. Its invasive ability gives it the highest incidence for malignancy of the oral cavity, characterized as local invasiveness and a propensity for

Correspondence to: Dr Jun Yamazaki, Department of Physiological Science and Molecular Biology, Fukuoka Dental College, 2-15-1 Tamura, Sawara-ku, Fukuoka 814-0193, Japan

E-mail: junyama@college.fdcnet.ac.jp

Key words: TRPM8, non-specific cation current, calcium, oral cancer, invasion dissemination to cervical lymph nodes (1). Some of the proteins involved in $\mathrm{Ca}^{2+}$ homeostasis are known to be associated with tumor progression $(2,3)$. In cancer cells, several members of the transient receptor potential (TRP)-channel family, which are $\mathrm{Ca}^{2+}$ - and $\mathrm{Na}^{+}$-permeable channels, have been shown to play certain roles in tumor progression (3). Originally, the TRP superfamily was reported to play an important role in sensory physiology (4). It is now classified into seven subfamilies, on the basis of homology, such as canonical channels (TRPC), vanilloid-receptor channels (TRPV), melastatin channels (TRPM), ankyrin channels (TRPA).

The TRP members reported to be expressed abundantly in cancer cells include TRPV1, TRPV6, TRPM1, and TRPM8 (trp-p8) (2). Expression of TRPV1, a sensor of both noxious heat $\left(>43^{\circ} \mathrm{C}\right)$ and capsaicin, is increased in cancers of the prostate, colon, pancreas, and bladder, as well as in oral cancer (5). Expression of TRPV1 is reportedly increased in parallel with an accelerated growth of an oral SCC cell line (5). In contrast, TRPM8 is activated by cooling $\left(<26^{\circ} \mathrm{C}\right)$ and by menthol $(6,7)$. TRPM8 was originally cloned from human prostate (8), but is also expressed in many types of tumor tissues, such as breast, colon, lung, and skin (2). In prostate cancer cells, transition from the androgen-dependent state to the androgen-independent state causes loss of TRPM8 (9). Although it seems possible that TRPM8 might also be involved in the pathophysiology of oral cancer cells, its expression and functional significance in such cells remain unclear. Unfortunately, in tissues expressing other TRP members the less-selective pharmacological tools currently available have limited the ability of basic research to identify pathophysiological roles for these TRPs $(3,10)$.

Recently, a potent and selective TRPM8 antagonist was reported. This agent, RQ-00203078 (RQ), exhibited potent antagonistic activity against menthol-induced $\mathrm{Ca}^{2+}$ influx in HEK-293 cells expressing human TRPM8 channels, while having little inhibitory action against TRPV1 $\left(\mathrm{IC}_{50}>30 \mu \mathrm{M}\right)$, TRPA1 $\left(\mathrm{IC}_{50}>10 \mu \mathrm{M}\right)$, TRPV4 $\left(\mathrm{IC}_{50}=10 \mu \mathrm{M}\right)$, or TRPM2 channels $\left(\mathrm{IC}_{50}>10 \mu \mathrm{M}\right)(11)$. Here, using RQ and the specific TRPM8 agonist WS-12 (10), we provide convincing evidence that TRPM8 mediates both cation permeability through plasma membranes and intracellular $\mathrm{Ca}^{2+}$ mobilization in two human oral SCC lines, HSC3 and HSC4, which originated from the human tongue. We also provide the first evidence that the TRPM8 antagonist RQ strongly inhibits both the migration and invasion abilities of these cells. These results should aid our 
understanding of the possible pathophysiological roles played by TRPM8 channels in oral cancer and support TRP proteins as valuable targets for pharmaceutical intervention in oral SCC.

\section{Materials and methods}

Cell culture. The HSC3 and HSC4 cell lines, derived from oral squamous cell carcinoma of the human tongue, were obtained from RIKEN Bioresource Center Cell Bank (Tsukuba, Ibaragi, Japan). Cells were grown in Dulbecco's modified Eagle's medium (DMEM; Invitrogen Corp./Gibco, CA, USA) in the presence of $10 \%$ heat-inactivated $\left(56^{\circ} \mathrm{C}, 40 \mathrm{~min}\right)$ fetal bovine serum (ICN Biomedicals Inc., OH, USA) plus penicillin $(10000 \mathrm{U} / \mathrm{ml})$ and streptomycin $(10000 \mu \mathrm{g} / \mathrm{ml})$. This was done in a humidified atmosphere of $95 \%$ air and $5 \% \mathrm{CO}_{2}$ at $37^{\circ} \mathrm{C}$.

RT-PCR analysis of the distribution of TRPM8 and other TRPs. Total RNA was extracted from the HSC 3 and HSC4 cells, and $2 \mu \mathrm{g}$ of this total RNA was reverse-transcribed using oligo(dT) primers. The resulting cDNA was subjected to PCR for 40 cycles (denaturation, $95^{\circ} \mathrm{C}, 30 \mathrm{sec}$; annealing at temperatures listed in Table I, $30 \mathrm{sec}$; extension, $72^{\circ} \mathrm{C}, 30 \mathrm{sec}$ ) using $5 \mathrm{U} / \mathrm{ml}$ of LA Taq polymerase (Takara Bio Inc., Tokyo, Japan) and specific primer pairs for TRPM8 and other TRPs (Table I). PCR products were analyzed on an ethidium bromide-stained agarose (3\%) gel.

Quantitative PCR (qPCR) was performed by means of an Applied Biosystems (ABI) 7500 real-time PCR system under the thermal cycling conditions recommended by the manufacturer, with the TaqMan ${ }^{\mathrm{TM}}$ method being used to target human TRPM8 (GenBank accession number:NM_024080.4) in HSC3 and HSC4 cells. The PCR primers and the $\mathrm{FAM}^{\mathrm{TM}}$-labeled MGB $^{\text {TM }}$ probe were purchased from ABI (Hs01066588_m1, TaqMan Gene Expression assay). The qPCR was performed on samples in triplicate. The comparative $\Delta \Delta \mathrm{C}_{\mathrm{T}}$ method was used to calculate the expression of human TRPM8 normalized to an endogenous control ( $\beta$-actin). The mean $\Delta \mathrm{C}_{\mathrm{T}}$ of HSC3 cells was used as an internal calibrator, and the relative quantity of TRPM8 in HSC4 cells was calculated as $2^{-\Delta \Delta \mathrm{C}_{\mathrm{T}}}$ [range $=$ $2^{-\left(\Delta \Delta \mathrm{C}_{\mathrm{T}} \mathrm{S}\right)}$ to $\left.2^{-\left(\Delta \Delta \mathrm{C}_{\mathrm{T}}+\mathrm{S}\right)}\right]$, where $S$ is SEM of the $\Delta \Delta \mathrm{C}_{\mathrm{T}}$ value.

Immunofluorescence. HSC 3 and HSC4 cells were cultured on type I-collagen-coated slide-glass attached to a media chamber (Lab-Tek II Chamber Slide, Nalge Nunc, IL, USA). The cells were washed with $\mathrm{Ca}^{2+}$ - and $\mathrm{Mg}^{2+}$-free phosphate buffer (PBS; $137 \mathrm{mM} \mathrm{NaCl}, 2.68 \mathrm{mM} \mathrm{KCl}, 8.1 \mathrm{mM} \mathrm{Na}{ }_{2} \mathrm{HPO}_{4}, 1.47 \mathrm{mM}$ $\mathrm{KH}_{2} \mathrm{PO}_{4}$ ), fixed with $4 \%$ paraformaldehyde in PBS for $20 \mathrm{~min}$ at $37^{\circ} \mathrm{C}$, then permeabilized with $0.1 \%$ Triton $\mathrm{X}-100$ for $5 \mathrm{~min}$. They were then washed $(4 \times 5 \mathrm{~min})$ and incubated with $10 \%$ goat serum for $30 \mathrm{~min}$ at room temperature, followed by a $2-\mathrm{h}$ incubation with rabbit anti-TRPM8 antibody (dilution, 1:400; ab3243, Abcam, Japan), three 5-min washes, a 1-h incubation with anti-rabbit IgG antibody (1:8000) conjugated with Alexa Fluor 488 (Molecular Probes Inc., OR, USA), and three 5-min washes. Nuclei were counterstained with DAPI (Molecular Probes Inc.). Fluorescence was observed using a confocal microscope (LSM710; Carl Zeiss MicroImaging GmbH, Germany). ZEN 2009 Light Edition (Carl Zeiss) and Adobe Photoshop 7.0 (Adobe Systems Incorp., CA, USA) were used for image processing.
Electrophysiology. For whole-cell patch-clamp recordings, cells were plated onto type I-collagen-coated glass coverslips (Matsunami, Japan) in a tissue-culture dish (Becton Dickinson, USA). The coverslips were transferred to a recording chamber mounted on the stage of a microscope (DM IRB; Leitz, Wetzlar, Germany). Currents were recorded via an EPC-9 amplifier (HEKA Elektronik GmbH, Lambrecht, Germany) in a wholecell configuration using a conventional patch-clamp technique (12). Electrode resistance in the bathing solution was 2-4 M $\Omega$ when filled with the pipette solution. The recorded currents were filtered at $5 \mathrm{kHz}$ and digitized on-line at $20 \mathrm{kHz}$ using EPC-9 connected to a Windows PC. The currents recorded during voltage-steps or -ramps were analyzed using PatchMaster V2 software (HEKA Elektronik, Lambrecht/Pfalz, Germany).

Cells were perfused with a bathing solution containing (in $\mathrm{mM}$ ): $150 \mathrm{NaCl}, 6 \mathrm{CsCl}, 1.5 \mathrm{CaCl}_{2}, 1.0 \mathrm{MgCl}_{2}, 10$ glucose, and 10 2-[4-(2-hydroxyethyl)-1-piperazinyl]ethanesulfonic acid (HEPES). Patch pipettes were filled with a solution containing (in mM): $150 \mathrm{NaCl}, 3 \mathrm{MgCl}_{2}, 5$ ethylene glycolbis(2-aminoethylether)- $N, N, N^{\prime}, N^{\prime}$-tetraacetic acid (EGTA), and 10 HEPES. The $\mathrm{pH}$ of the bathing solution was adjusted to 7.4 and that of the pipette solution to 7.2 using $\mathrm{NaOH}$. Experiments were conducted at $25-26^{\circ} \mathrm{C}$, unless otherwise indicated. A concentration-current curve for menthol was fitted with a sigmoidal equation using 4 parameters: $y=y_{\min }+y_{\max } /\{1+\exp$ $\left[-\left([\right.\right.$ menthol $\left.\left.\left.]-\mathrm{EC}_{50}\right) / n\right]\right\}$, where $y_{\min }$ and $y_{\max }$ are the minimum and maximum currents, respectively, $\mathrm{EC}_{50}$ is the $50 \%$ effective concentration of menthol, and $n$ is the slope factor.

For monovalent cation-substitution experiments, the bath solution was changed to (in $\mathrm{mM}) 140 \mathrm{NaCl}(140 \mathrm{KCl}$ or 140 NMDG), 10 glucose, and 10 HEPES (adjusted to pH 7.4 with $\mathrm{NaOH}, \mathrm{KOH}$, or $\mathrm{HCl}$, respectively). For divalent cationpermeability experiments, the bath solution was changed to (in mM) $125 \mathrm{NMDG}, 10 \mathrm{CaCl}_{2}, 10$ glucose, and $10 \mathrm{HEPES}$ (adjusted to $\mathrm{pH} 7.4$ with $\mathrm{HCl}$ ). The pipette solution contained (in $\mathrm{mM}$ ) $140 \mathrm{NaCl}, 5$ EGTA, and 10 HEPES (adjusted to $\mathrm{pH} 7.2$ with $\mathrm{NaOH}$ ). Liquid junctional potentials were corrected. The reversal potential $\left(E_{\mathrm{rev}}\right)$ was measured in each bath solution using voltage-ramps. The permeability ratio for a monovalent cation $\left(\mathrm{X}^{+}\right)$to $\mathrm{Na}^{+}\left(P_{\mathrm{X}} / P_{\mathrm{Na}}\right)$ was calculated as follows: $P_{\mathrm{X}} / P_{\mathrm{Na}}=$ $\alpha_{\mathrm{Na}}\left[\mathrm{Na}^{+}\right]_{\mathrm{in}} / \alpha_{\mathrm{X}}\left[\mathrm{X}^{+}\right]_{\text {out }} \exp \left\{F / R T\left(E_{\mathrm{rev}(\mathrm{X})}-E_{\mathrm{rev}(\mathrm{Na})}\right)\right\}$, where $\alpha$ is the assumed ion-activity coefficient ( 0.75 for monovalent cations), $F$ is Faraday's constant, $R$ is the universal gas constant, and $T$ is the absolute temperature. For measurements of $\mathrm{Ca}^{2+}$ permeability, $P_{\mathrm{Ca}} / P_{\mathrm{Na}}$ was calculated as follows: $P_{\mathrm{Ca}} / P_{\mathrm{Na}}=\left[\alpha_{\mathrm{Na}}\left[\mathrm{Na}^{+}\right]_{\mathrm{in}}\right.$ $\exp \left\{F / R T\left(E_{\mathrm{rev}(\mathrm{NMDG}+\mathrm{Ca})}-E_{\mathrm{rev}(\mathrm{Na})}\right)\right\}-\alpha_{\mathrm{NMDG}}\left[\mathrm{NMDG}^{+}\right]_{\text {out }} P_{\mathrm{NMDG}} /$ $\left.P_{\mathrm{Na}}\right] \cdot\left[1+\exp \left\{F / R T\left(E_{\mathrm{rev}(\mathrm{NMDG}+\mathrm{Ca})}-E_{\mathrm{rev}(\mathrm{Na})}\right)\right\}\right] / 4 \alpha_{\mathrm{Ca}}\left[\mathrm{Ca}^{2+}\right]_{\text {out }}$ $(\alpha=0.25)$.

$\mathrm{Ca}^{2+}$ measurements by fluorescence imaging. Cells plated on glass coverslips were incubated with Fura- 2 acetoxymethyl ester (Dojindo, Kumamoto, Japan) for $30 \mathrm{~min}$ at $37^{\circ} \mathrm{C}$ in the dark. After a 30-min additional incubation, the coverslips were transferred to a recording chamber mounted on the stage of a microscope equipped with a cooled CCD camera (EM-CCD; Hamamatsu Photonics, Japan). Fura-2 was excited alternatively at 340 and $380 \mathrm{~nm}$ using a variable-filter wheel (Lambda 10-2; Sutter Instruments). The emitted fluorescence was collected through a $510 \mathrm{~nm}$ band-pass filter. Dual images were captured and the ratio of fluorescence intensities at two wavelengths 
Table I. Primer pairs used for detection of TRP channels and GAPDH.

\begin{tabular}{|c|c|c|c|c|}
\hline Gene name & $\begin{array}{c}\text { GenBank } \\
\text { accession no. }\end{array}$ & Primers & $\begin{array}{l}\text { PCR products } \\
\text { (bp) }\end{array}$ & $\begin{array}{l}\text { Annealing temp. } \\
\qquad\left({ }^{\circ} \mathrm{C}\right)\end{array}$ \\
\hline TRPM8 & NM_024080 & $\begin{array}{l}\text { F: GGAGAACAATGACCAGGTCT } \\
\text { R: GGTGTCGTTGGCTTTTGTGT }\end{array}$ & 262 & 59 \\
\hline TRPV1 & NM_080704 & $\begin{array}{l}\text { F: TGTGCCGTTTCATGTTT } \\
\text { R: TGCAGCTTCCAGATGTT }\end{array}$ & 373 & 60 \\
\hline TRPV3 & NM_145068 & $\begin{array}{l}\text { F: CCATCCСТCTGCCTGCAATGA } \\
\text { R: GGAGAAGACAGGAGGAGAGGT }\end{array}$ & 322 & 64 \\
\hline TRPV6 & NM_018646 & $\begin{array}{l}\text { F: GGAGCAAGTTCTGCAGATGGT } \\
\text { R: GCACCTTGCAATCCTCATACT }\end{array}$ & 171 & 64 \\
\hline TRPA1 & NM_007332 & $\begin{array}{l}\text { F: GCGTTAAGTTTCTTCTCA } \\
\text { R: GTGCAACTGTCTACTGTA }\end{array}$ & 356 & 58 \\
\hline GAPDH & NM_002046 & $\begin{array}{l}\text { F: CCAACGTCCATGCCATCACTG } \\
\text { R: CCTGCTTTCACCACCTTCTTGA }\end{array}$ & 267 & 57 \\
\hline
\end{tabular}

$\left(\mathrm{F}_{340} / \mathrm{F}_{380}\right)$ was calculated using Aquacosmos ver. 2.6 software (Hamamatsu). Intracellular $\left[\mathrm{Ca}^{2+}\right]$ was estimated from the calibration equation and dissociation constant $(\sim 200 \mathrm{nM})$ of Fura-2 reported by Grynkiewicz et al (13).

Cell viability test. To examine cell-proliferation ability, cell viability was measured using Cell Counting kit-8 (Dojindo) at 36,48 , or $72 \mathrm{~h}$ after the cells had been seeded in 96-well plates to which drug- or vehicle-containing DMEM had been added. As per the manufacturer's instructions, the cells were incubated with the water-soluble tetrazolium salt, WST-8, which is converted to orange formazan by dehydrogenase activity in living cells in the presence of an electron mediator. Absorbance at $460 \mathrm{~nm}$ was measured using a microplate reader (1420 ARVO MX; PerkinElmer Inc., MA, USA).

Cell motility assay. Following cell culture in DMEM with $10 \%$ FBS, the monolayer of confluent HSC3 or HSC4 cells was scratched by a 200- $\mu 1$ pipette tip to form a wound area. The cells were cultured for an additional 12-18 h in either vehicle or drug-containing DMEM. The wound area was calculated using Image J $1.37 \mathrm{v}$ software (NIH, MD, USA), and the migration distance of the leading edge of the monolayer was estimated.

Chemoinvasion assay. HSC3 or HSC4 cells ( $2 \times 10^{4}$ cells) were suspended in $0.5 \mathrm{ml}$ DMEM without serum, and then seeded in a rehydrated insert of a 24-well BioCoat Matrigel ${ }^{\mathrm{TM}}$ Invasion Chamber (Beckton Dickinson, Bedford, MA, USA). The inserts were transferred to wells containing $0.75 \mathrm{ml}$ DMEM (without serum). The DMEM contained $10 \mathrm{ng} / \mathrm{ml}$ EGF as a chemoattractant for the oral cancer cell lines HSC 3 and SAS cells (14). Following a 22-h incubation with drug or vehicle, non-invading cells were removed from the upper surface of the membrane of the inserts by scrubbing. The membrane was stained using a Diff-Quik staining kit (Sysmex, Kobe, Japan), and the number of cells penetrating to the lower surface of the membrane was counted.

Gelatin zymography. Serum-free conditioned medium was collected from HSC3 and HSC4 cells treated with drug or vehicle, in each case in the presence of EGF as a chemoattractant. The medium was concentrated 10 -fold, treated with Laemmli loading buffer, and separated on SDS-polyacrylamide (7\%) gel containing $0.1 \%$ gelatin under native conditions (15). Gels were washed in $2 \%$ Triton X-100 containing $50 \mathrm{mM}$ Tris- $\mathrm{HCl}$ (pH 7.4) buffer, followed by incubation at $37^{\circ} \mathrm{C}$ for $14 \mathrm{~h}$ with $50 \mathrm{mM}$ Tris- $\mathrm{HCl}$ (pH 7.4) buffer containing $5 \mathrm{mM}$ $\mathrm{CaCl}_{2}, 200 \mathrm{mM} \mathrm{NaCl}, 1 \%$ Triton X-100, and $0.02 \% \mathrm{NaN}_{3}$. Gels were stained with $0.2 \%$ Coomassie Brilliant Blue G250 in 25\% methanol and $10 \%$ acetic acid for $30 \mathrm{~min}$, then destained in $20 \%$ methanol and $10 \%$ acetic acid. Densitometric analysis of the gels was performed using ImageJ software (NIH).

Chemicals. RQ-00203078 (RQ) was a generous gift from RaQualia Pharma. Inc., Japan. RQ and other commercially available compounds were dissolved in dimethylsulfoxide (DMSO; Sigma-Aldrich Co., MO, USA) as 10 or $100 \mathrm{mM}$ stock solutions, which were stored at $-20^{\circ} \mathrm{C}$. Human recombinant EGF (R\&D systems, MN, USA) was dissolved in $10 \mathrm{mM}$ acetic acid to make a stock solution $(500 \mu \mathrm{g} / \mathrm{ml})$.

Statistics. All values are presented as means \pm SEM (n, number of observations). Statistical analysis was performed using a paired or unpaired t-test when two groups were to be compared or by a one-way analysis of variance (ANOVA) followed by a post hoc Scheffe's t-test for more than three groups. A p $<0.05$ was considered to be statistically significant.

\section{Results}

Expressions of mRNA and proteins of TRP channels in HSC cell lines. To examine which types of TRP channels might be present in carcinoma cell lines derived from the human tongue, we performed RT-PCR using total RNA extracted from HSC3 and HSC4 cells by means of pairs of primers designed to recognize the mRNA of several TRP members (Table I). TRPM8 mRNA expression was observed at the predicted nucleotide size of 262 bp in both HSC cell lines, while TRPV1, TRPV3, TRPV6, and TRPA1 were also expressed in these cells (Fig. 1A). We then performed a quantitative evaluation 

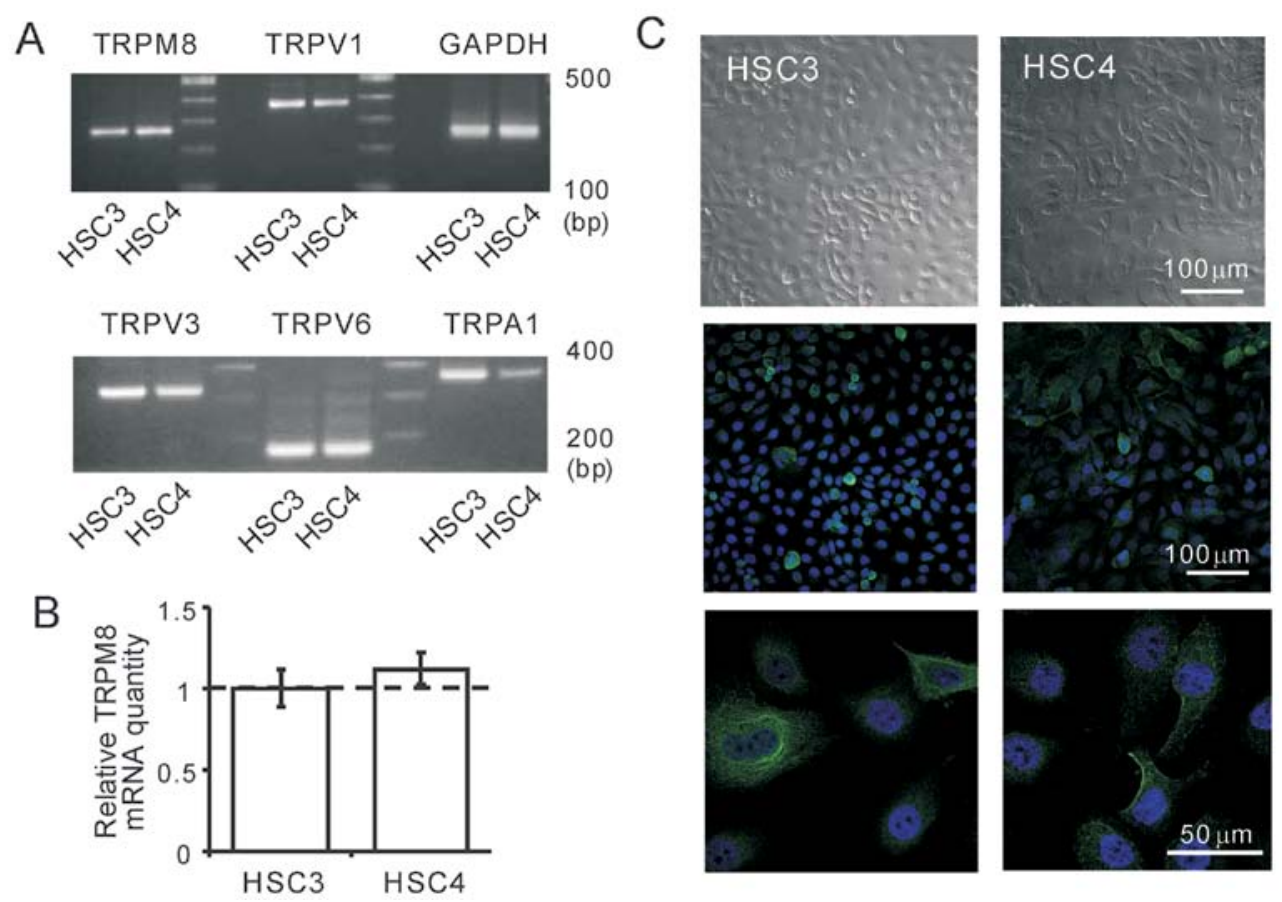

Figure 1. RT-PCR and immunofluoresence results. (A) mRNA expressions for TRP channels as detected by RT-PCR. (B) Quantity of TRPM8 mRNA, as measured using real-time PCR procedures. Mean $2^{-\Delta \Delta \mathrm{C}_{\mathrm{T}}}$ values with their ranges $(\mathrm{n}=3)$ are shown. (C) Subcellular localization of TRPM8, as detected by a selective antibody. Top, differential interference contrast (DIC) images; middle and bottom, fluorescence images (TRPM8, green; nucleus, blue).

of TRPM8 mRNA using real-time PCR procedures $\left(\Delta \Delta \mathrm{C}_{\mathrm{T}}\right.$ method). The quantity of TRPM8 mRNA in HSC4 cells was not different from that in HSC3 cells (Fig. 1B).

Next, we performed immunocytochemistry for TRPM8 protein using permeabilized HSC 3 and HSC 4 cells. Interestingly, TRPM8 appeared not to be evenly localized within all cells. Specific TRPM8 antibody recognized a broader population of HSC4 cells than of HSC 3 cells (Fig. 1C). TRPM8 was expressed on the plasma membrane and also within the intracellular area in some HSC3 cells, with a marked reticular staining. In contrast, TRPM8 was predominantly expressed on an intense lining around some HSC4 cells, indicating its localization to the plasma membrane (Fig. 1C).

Electrophysiological response to TRPM8 agonist and antagonist in HSC cell lines. Fig. 2A shows an example of a membrane-current recording under voltage-clamp conditions in an HSC3 cell. We found an unidentified basal current flow at temperatures above $27^{\circ} \mathrm{C}$, and so bath temperature was kept at $25-26^{\circ} \mathrm{C}$ in the patch-clamp study, unless otherwise indicated. Menthol-induced TRPM8 currents are known to exhibit strong rectification at $34^{\circ} \mathrm{C}$, being much greater at positive potentials than at negative potentials (16). Decreasing temperature moves the activation curves to the left along the voltage axis, and menthol shifts the curves further toward physiological membrane potentials at $24^{\circ} \mathrm{C}(16)$. Hence, outward rectification appeared to be modest at $24^{\circ} \mathrm{C}$. Here, we found that menthol (10-100 $\mu \mathrm{M})$ induced a concentration-dependent inward current at $-50 \mathrm{mV}$ with variable latency $(0.5-1 \mathrm{~min})$, as in a previous study (17), increasing the ionic current with modest rectification during voltage ramps.

To try to determine whether TRPM8 is involved in the menthol-induced response, we used RQ (10 $\mu \mathrm{M})$, a selective antagonist of TRPM8 (11). RQ completely inhibited the menthol-induced current (Fig. 2A). Fig. 2B shows the superimposed current traces evoked by various holding-potential changes from $-50 \mathrm{mV}$ to voltages from -100 to $100 \mathrm{mV}$. Menthol $(100 \mu \mathrm{M})$ increased the ionic currents (a to b), and this effect was diminished in the concomitant presence of RQ (c). Fig. 2C shows the concentration-dependency of the menthol-induced current. Menthol $(100 \mu \mathrm{M})$ evoked its maximum responses at -100 and $100 \mathrm{mV}$. All the data obtained from 4 cells were fitted with a sigmoidal equation. $\mathrm{EC}_{50}$ was estimated to be $75.7 \mu \mathrm{M}$ at $100 \mathrm{mV}$ and $85.2 \mu \mathrm{M}$ at $-100 \mathrm{mV}$.

Next, to examine monovalent and divalent cation permeability in HSC3 cells, external $\mathrm{Na}^{+}(140 \mathrm{mM})$ was replaced with either $\mathrm{K}^{+}(140 \mathrm{mM})$ or NMDG $(140 \mathrm{mM})$, or with NMDG (125 mM) plus $\mathrm{Ca}^{2+}(10 \mathrm{mM})$. The intracellular $\left[\mathrm{Na}^{+}\right]$ was $140 \mathrm{mM}$. The reversal potential of the menthol-induced current was $-0.84 \pm 0.1 \mathrm{mV}(\mathrm{n}=4)$ in external $\mathrm{Na}^{+}$solution, but $-0.86 \pm 0.1 \mathrm{mV}(\mathrm{n}=4)$ in the $\mathrm{K}^{+}$solution, $-35.4 \pm 3.7 \mathrm{mV}(\mathrm{n}=4)$ in the NMDG solution, and $-17.1 \pm 0.7 \mathrm{mV}(\mathrm{n}=4)$ in the NMDG plus $\mathrm{Ca}^{2+}$ solution (Fig. 2D). The relative permeability of each cation $\left(P_{\mathrm{x}} / P_{\mathrm{Na}}\right)$, as estimated from the Goldman-Hodgkin Katz equation, was $0.99 \pm 0.002$ for $\mathrm{K}^{+}, 0.26 \pm 0.04$ for $\mathrm{NMDG}$, and $4.66 \pm 0.38$ for $\mathrm{Ca}^{2+}$, suggesting the involvement of nonspecific cation channels in the menthol-induced current recorded from HSC3 cells. In addition to their sensitivity to menthol, HSC 3 cells were sensitive to cooling (Fig. 2E). When the temperature of the external solution was decreased from $26^{\circ} \mathrm{C}$ to $17^{\circ} \mathrm{C}$, the basal inward current recorded at $-50 \mathrm{mV}$ was progressively enhanced, and this effect was reversed in the presence of RQ.

In agreement with the immunocytochemistry data regarding the populations of cells exhibiting surface TRPM8, more HSC4 cells than HSC3 cells possessed the TRPM8-mediated 
A

menthol $10 \mu \mathrm{M} \quad 30 \mu \mathrm{M} \quad 100 \mu \mathrm{M} \quad 10 \mu \mathrm{M} \mathrm{RQ}$

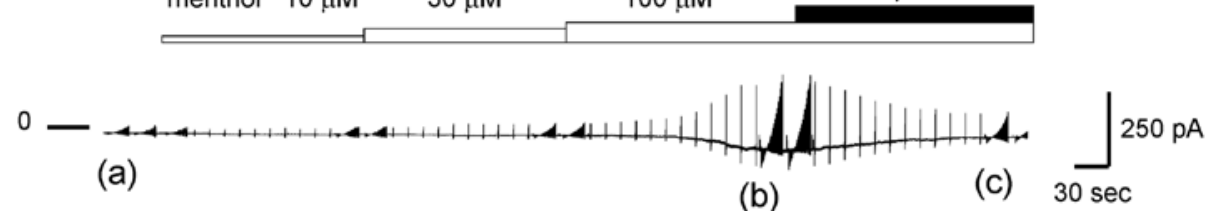

B

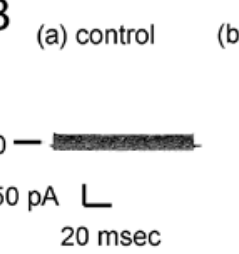

(b) $100 \mu \mathrm{M}$ menthol

(c) $100 \mu \mathrm{M}$ menthol

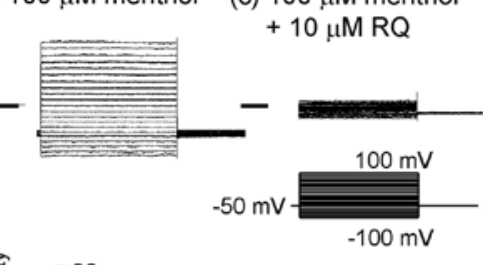

C
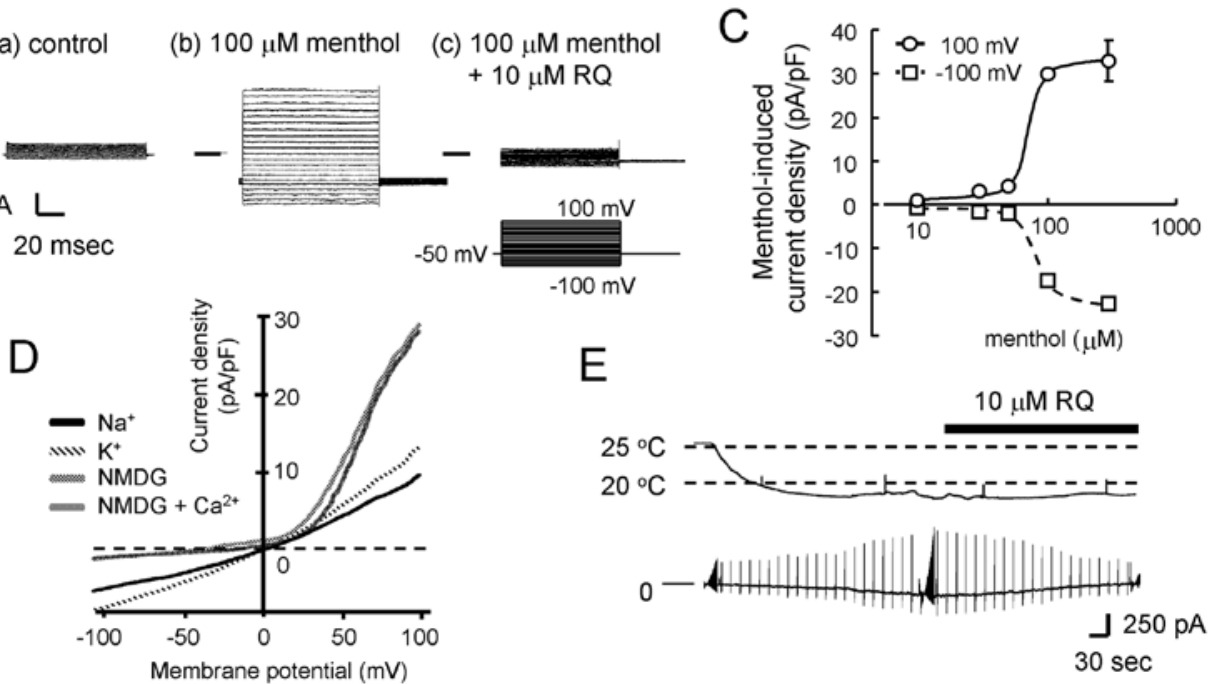

E

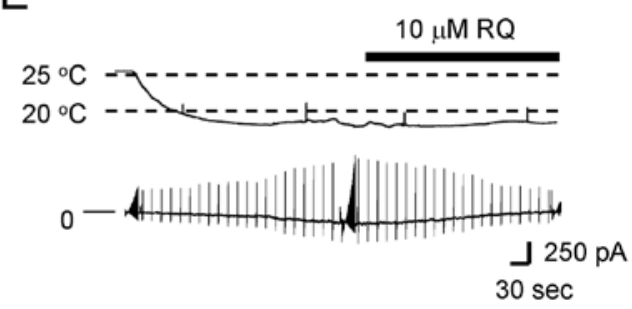

Figure 2. TRPM8-mediated whole-cell currents recorded from HSC3 cells. (A) Basal current traces were obtained at a holding potential of -50 mV. Voltage ramps and steps were applied intermittently. (B) Current traces were superimposed for each period (a-c) shown in (A) during voltage steps (100 msec) applied from a holding potential of $-50 \mathrm{mV}$ to potentials within the range -100 to $100 \mathrm{mV}$ (interval, $10 \mathrm{mV}$ ). (C) Concentration-dependency of menthol-induced currents at -100 or $100 \mathrm{mV}$ in 4 cells. (D) Menthol $(100 \mu \mathrm{M})$-sensitive whole-cell currents recorded in external solutions including various cations. Difference current at each voltage was obtained by subtracting current recorded before adding menthol from that recorded during treatment. (E) Sensitivity of an HSC3 cell to cooling.
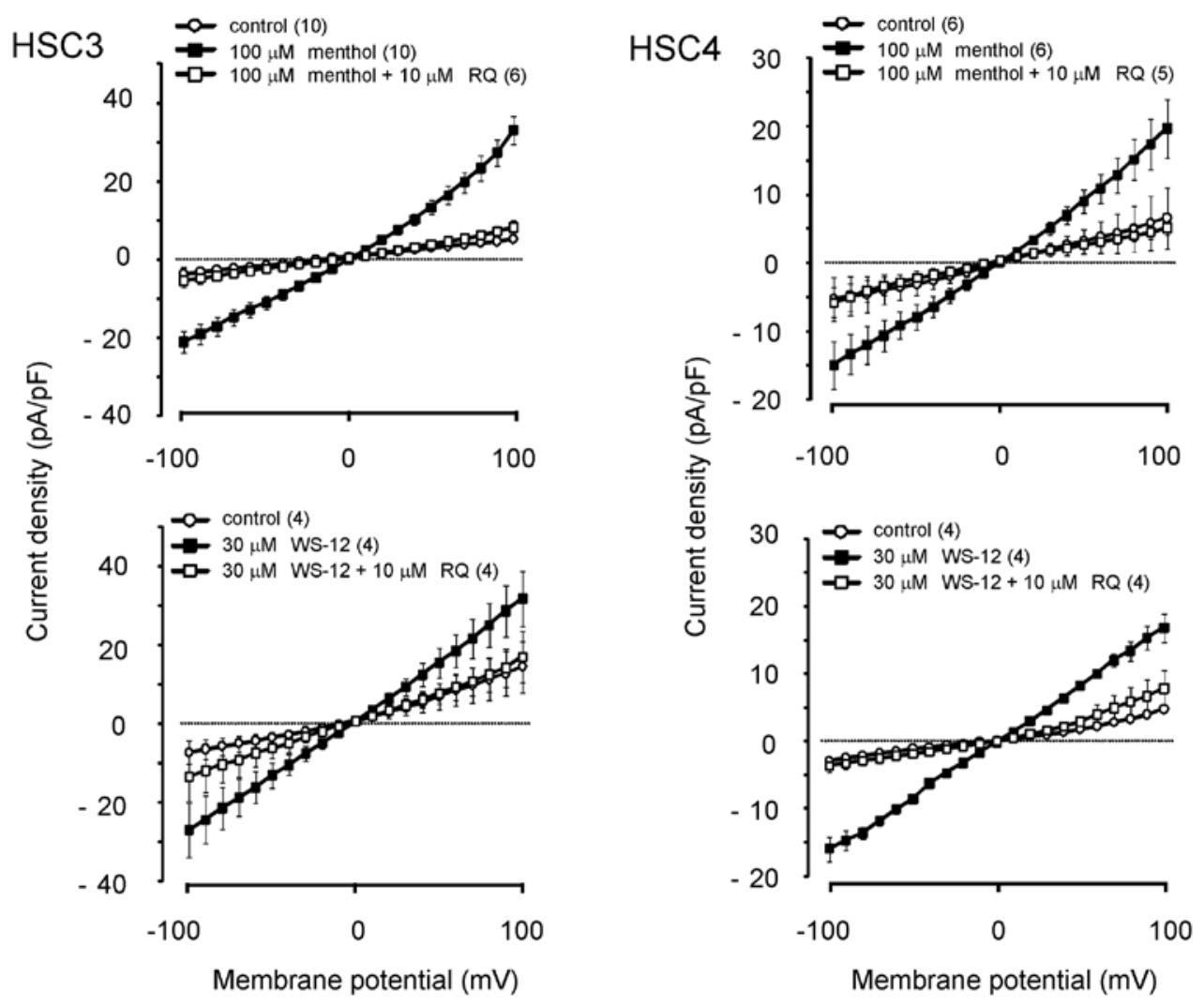

Figure 3. Current-voltage (IV) relationships were obtained from HSC cell lines treated with TRPM8-related compounds, either alone or in combination. Voltage steps were applied from a holding potential of $-50 \mathrm{mV}$ to potentials within the range -100 to $100 \mathrm{mV}$ (interval, $10 \mathrm{mV}$ ). I-V relationships were derived from grouped current-density data before (control) and during treatment with either menthol $(100 \mu \mathrm{M})$ or WS-12 $(30 \mu \mathrm{M})$, and with either of these agonists plus RQ $(10 \mu \mathrm{M})$. Numbers in parenthesis denote number of cells tested. 


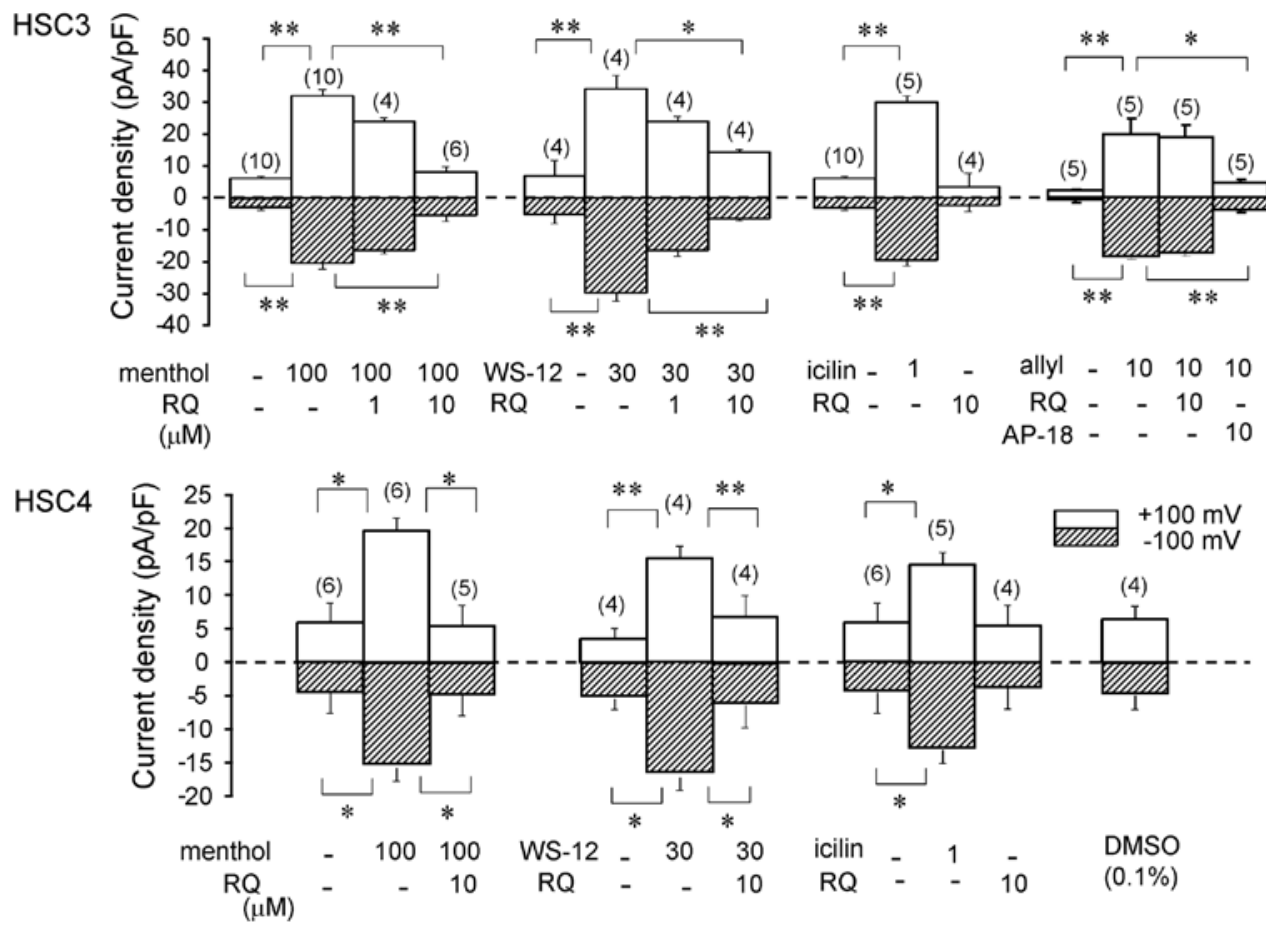

Figure 4. Summarized data for the current densities induced by TRPM8-related compounds. Holding potentials were -100 and $100 \mathrm{mV}$. Numbers in parenthesis denote the number of cells tested. ${ }^{*}<<0.05,{ }^{* *} \mathrm{p}<0.01$.

electrophysiological function. Approximately $66 \%$ of HSC4 cells and $44 \%$ of HSC3 cells exhibited a menthol-induced increase in current density (judged by the creation of more than $5 \mathrm{pA} / \mathrm{pF}$ at $100 \mathrm{mV})$.

In both HSC3 and HSC4 cells, the I-V relationship for menthol-induced currents displayed slight outward rectification and reversed near $0 \mathrm{mV}$ (Fig. 3). In HSC3 cells, RQ virtually abolished the response to menthol at all voltage steps within the range -100 to $100 \mathrm{mV}$. A similar finding was made for HSC4 cells (Fig. 3). Therefore, we performed similar experiments using a more specific TRPM8 agonist, WS-12 (10). WS-12 (30 $\mu \mathrm{M})$ augmented the currents in both HSC3 and HSC4 cells, an effect that was powerfully inhibited by RQ in each cell line (Fig. 3). Fig. 4 summarizes the current-density data recorded from HSC3 and HSC4 cells in the presence of one of these TRPM8 agonists (menthol, icilin, or WS-12) with or without the TRPM8 antagonist RQ. Neither RQ alone $(10 \mu \mathrm{M})$ nor DMSO $(0.1 \%)$ altered the current. Each of the TRPM8 agonists significantly increased the inward and outward currents recorded from HSC3 and HSC4 cells during voltage steps at -100 and $100 \mathrm{mV}$. Both the menthol-induced effect and the WS-12-induced effect were significantly inhibited by RQ at either membrane potential in a concentration-dependent manner (1-10 $\mu \mathrm{M})$. We further tested whether RQ would affect TRPA1, which is known to be activated both by noxious cold stimulation and by mustard oil (allylisothiocyanate; 'allyl') since our PCR study indicated expression of TRPA1 in HSC3 cells (see Fig. 1). TRPA1 expression seemed to be variable since we were able to detect allylisothiocyanate $(10 \mu \mathrm{M})$-induced current in only 5 of the 20 cells tested. In such cells, the induced currents were not altered by RQ $(10 \mu \mathrm{M})$, but they were significantly suppressed by a TRPA1-channel antagonist, AP-18 $(10 \mu \mathrm{M})$ (Fig. 4). These results suggest that RQ is able to discriminate between the two classes of cold-sensing channels.

TRPM8-mediated intracellular $\mathrm{Ca}^{2+}$ release and store-operated $\mathrm{Ca}^{2+}$ entry in HSC cell lines. To examine the roles of intracellular TRPM8 proteins in $\mathrm{Ca}^{2+}$ mobilization in SCC cell lines, we made fluorometric $\left[\mathrm{Ca}^{2+}\right]_{\mathrm{i}}$ measurements in HSC3 and HSC4 cells. In the absence of extracellular $\mathrm{Ca}^{2+}$, menthol $(100 \mu \mathrm{M})$ induced a transient increase in $\mathrm{F}_{340} / \mathrm{F}_{380}$ (closed circles in Fig. 5A), indicating $\mathrm{Ca}^{2+}$ release from intracellular store sites, such as the endoplasmic reticulum (ER), as previously shown in prostate cancer cells $(18,19)$. In the continued presence of menthol, addition of extracellular $\mathrm{Ca}^{2+}$ caused an immediate $\mathrm{F}_{340} / \mathrm{F}_{380}$ increase due to stimulation of store-operated $\mathrm{Ca}^{2+}$ entry, at least partly through TRPM8 channels located on the plasma membrane. Very recently, the lower sensitivity to some TRPM8 blockers shown by prostate cancer cells was suggested to be due to the poor accessibility of intracellular channels to these drugs (20). Notably, the continued presence of RQ significantly attenuated both the menthol-induced $\left[\mathrm{Ca}^{2+}\right]_{\mathrm{i}}$ elevation associated with intracellular $\mathrm{Ca}^{2+}$ release and the menthol-induced store-operated $\mathrm{Ca}^{2+}$ entry (open circles in Fig. 5A and B). These results suggest that intracellular TRPM8 channels function as $\mathrm{Ca}^{2+}$-release ER channels, and that these are sensitive to RQ. Fig. 5C shows that $R Q$ alone decreased $\left[\mathrm{Ca}^{2+}\right]_{\mathrm{i}}$ in the presence of extracellular $\mathrm{Ca}^{2+}$ in both cell lines, suggesting that TRPM8 channels are activated to some extent in the basal condition.

TRPM8-mediated effects on the proliferation of HSC cell lines. To examine whether TRPM8-related compounds are components of signaling pathways involved in cell proliferation, HSC3 and HSC4 cells were incubated with menthol, RQ, or a combination of the two, and cell viability was measured at 

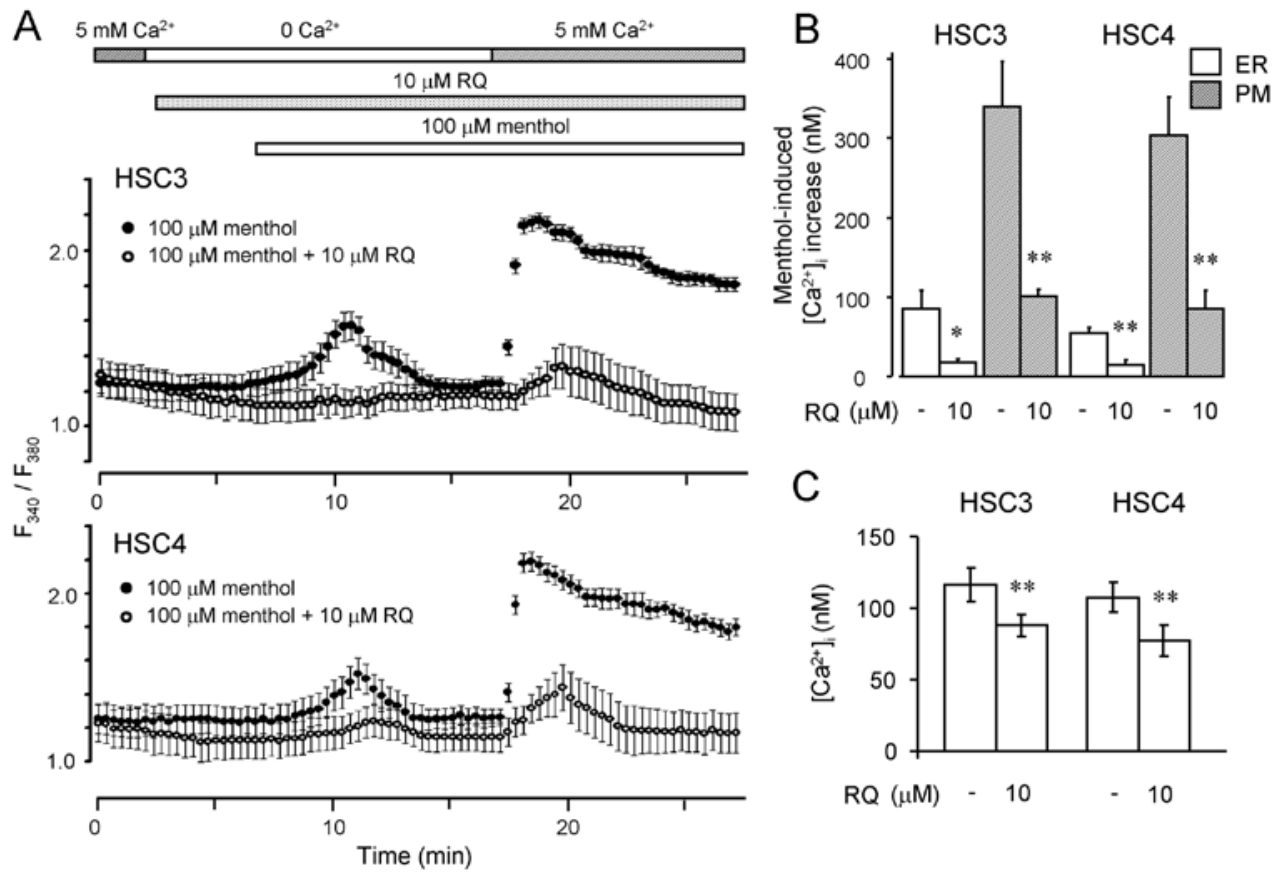

Figure 5. Intracellular $\mathrm{Ca}^{2+}$ imaging. (A) Time courses obtained for F340/F380 can be compared between HSC3 ( $\mathrm{n}=7$ ) and HSC4 cells ( $\mathrm{n}=5$ ) loaded with Fura-2 Menthol was perfused in $\mathrm{Ca}^{2+}$-free or $\mathrm{Ca}^{2+}$-containing solution in the presence or absence of RQ. (B) Summarized data for the menthol-induced [Ca $\left.{ }^{2+}\right]_{\mathrm{i}}$ increases obtained in the presence or absence of RQ $(n=7)$. Changes in $\left[\mathrm{Ca}^{2+}\right]_{\mathrm{i}}$ in $\mathrm{Ca}^{2+}$-free and $\mathrm{Ca}^{2+}$-containing solutions correspond to Ca ${ }^{2+}$ release from the ER and store-operated $\mathrm{Ca}^{2+}$ entry through the plasma membrane (PM), respectively. Mean $\pm \mathrm{SEM},{ }^{*} \mathrm{p}<0.05,{ }^{* *} \mathrm{p}<0.01$; compared to the corresponding menthol group. (C) RQ-induced decrease in $\left[\mathrm{Ca}^{2+}\right]_{\mathrm{i}}$ in $\mathrm{Ca}^{2+}$-containing solution ( $\left.\mathrm{n}=7\right)$. ${ }^{* *} \mathrm{p}<0.01$ compared to without $\mathrm{RQ}$ (paired t-test).
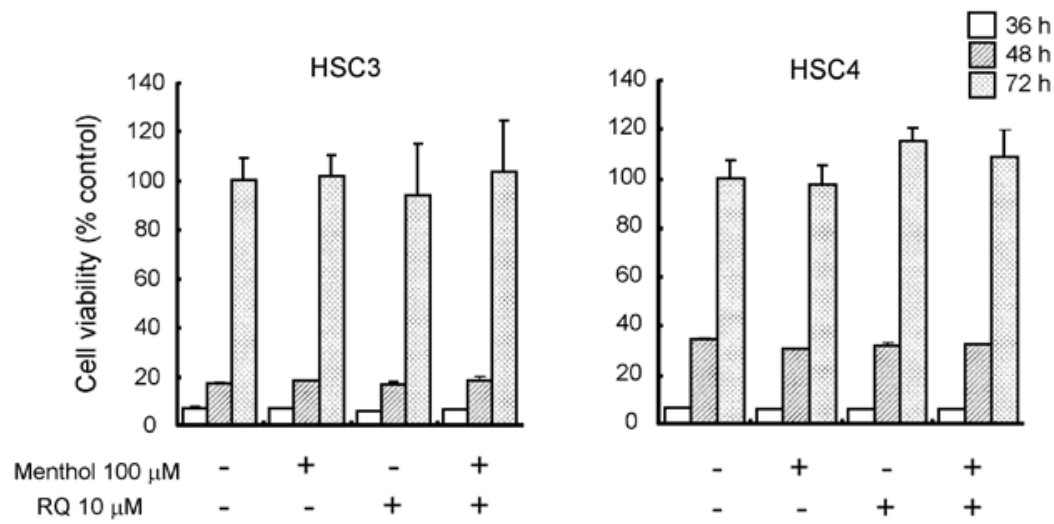

Figure 6. Cell viability tests. $\mathrm{HSC} 3$ and $\mathrm{HSC} 4$ cells were treated at $37^{\circ} \mathrm{C}$ for 36,48 , or $72 \mathrm{~h}$ with menthol, RQ, a combination of the two, or vehicle. Cell viability was assessed for each period using the tetrazolium salt WST-8 (see Materials and methods for cell viability test), and each value was compared with the $72 \mathrm{~h}$-value obtained from the non-treated cells. Mean \pm SEM of 4 determinations.

several time-points using WST-8 (see Materials and methods for cell viability test). The time-dependent values obtained for the cell viability in a given cell line were similar among the various conditions (Fig. 6), suggesting little contribution of TRPM8 to cell proliferation.

TRPM8-mediated effects on cell-motility and -invasion in HSC cell lines. Next, we studied the involvement of TRPM8 in the motility and invasive ability of HSC3 and HSC4 cells. Cell motility was estimated using a wound-healing assay, with the migration distance of the cells being calculated from the decrease in wound area after scratching. In both cell lines, the leading edge of the confluent monolayer migrated into the cell-free area (Fig. 7). In the serum-free condition, menthol significantly increased migration in both cell types, while RQ significantly decreased the migration distance (both in the presence and absence of menthol) to a level below the migration distance measured in the control condition. These results suggest the involvement of both menthol-activated and basally activated TRPM8 in such RQ-blockable cell motility.

Some oral SCC cell lines are malignant because of their high invasive abilities. To assess whether the abilities of HSC3 and HSC4 cells to penetrate the basement membrane would be altered by either activation or inhibition of TRPM8 channels, we performed a chemoinvasion assay using Matrigel matrix coated onto membrane filters (Fig. 8A). EGF was used as a chemoattractant (14). In HSC 3 cells, menthol $(100 \mu \mathrm{M})$ significantly increased the number of invading cells, and RQ $(10 \mu \mathrm{M})$ 

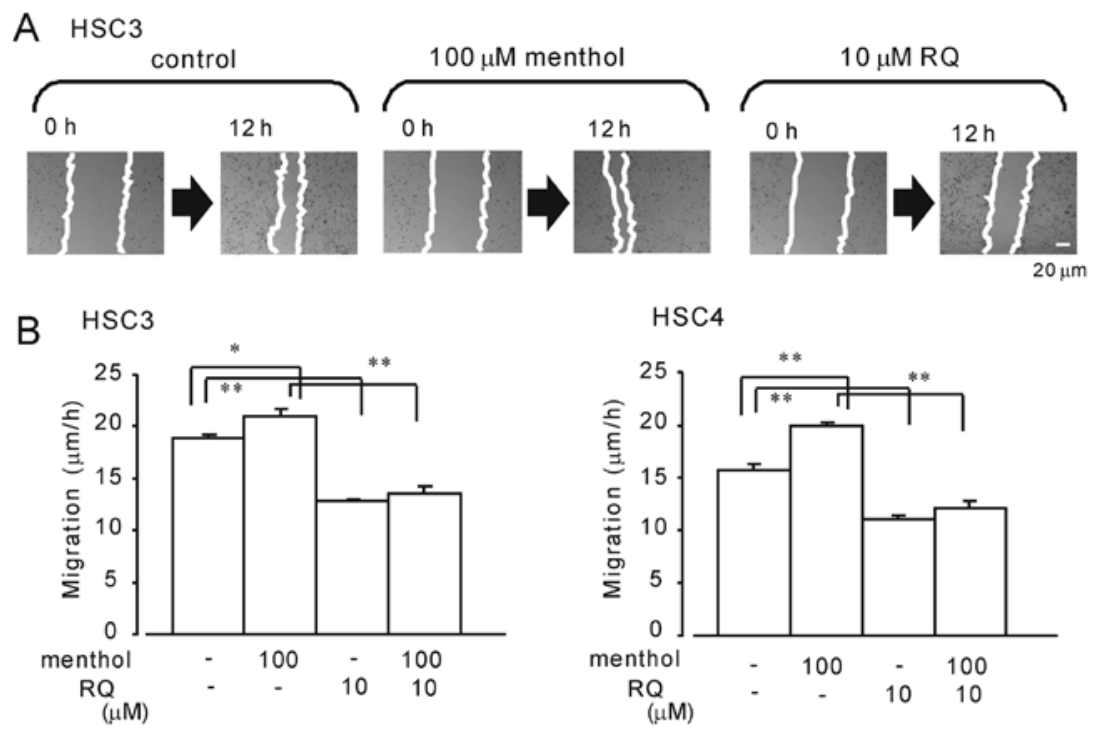

Figure 7. Motility measurements. A confluent monolayer of cultured HSC3 or HSC4 cells was scratched, and incubated at $37^{\circ} \mathrm{C}$ with menthol, RQ, a combination of the two, or vehicle. Serum was not included. Panels show representative images photographed at $12 \mathrm{~h}$ after the beginning of incubation (A) and calculated migration distance $(\mu \mathrm{m})$ achieved in $1 \mathrm{~h}(\mathrm{~B}) .{ }^{*} \mathrm{p}<0.05,{ }^{* *} \mathrm{p}<0.01$.

A $\mathrm{HSC}_{3}$

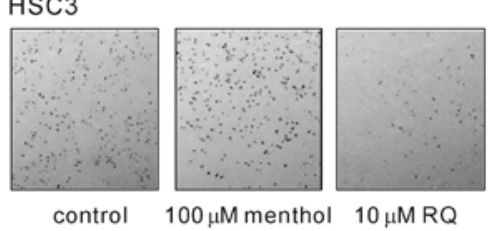

B

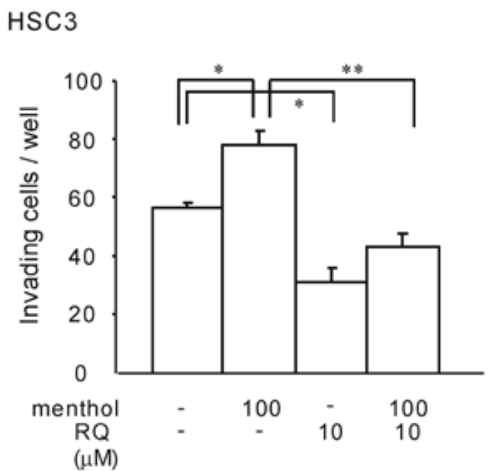

HSC4

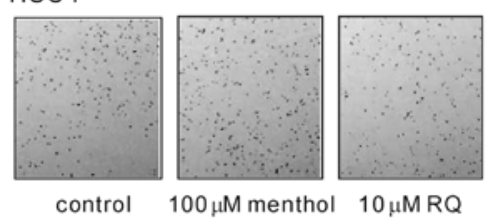

HSC4

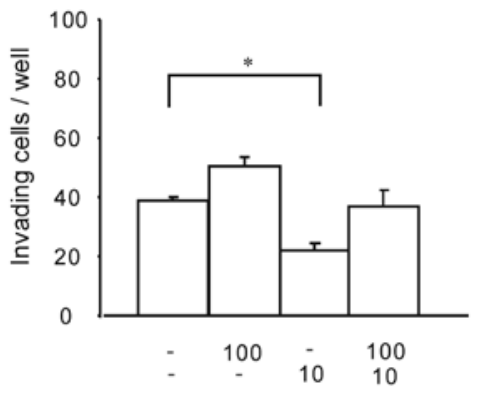

Figure 8. Invasion activity measurements. $\mathrm{HSC} 3$ and $\mathrm{HSC} 4$ cells were treated for $22 \mathrm{~h}$ with menthol, RQ, a combination of the two, or vehicle, all at $37^{\circ} \mathrm{C}$. EGF (10 ng/ml) was used as a chemoattractant for these cells. Panels show representative images for HSC3 and HSC4 penetrating the membrane filters (A) and summarized data (B). ${ }^{*} \mathrm{p}<0.05,{ }^{* *} \mathrm{p}<0.01$.

inhibited their invading ability in the presence or absence of menthol (Fig. 8B). In the case of HSC4 cells, no effect of menthol was apparent, but RQ had an inhibitory effect on their invading ability in the absence of menthol (Fig. 8B). Using gelatin zymography, we confirmed that menthol significantly augmented the MMP-9 activity, but only slightly increased MMP-2 activity in each of the EGF-treated HSC cell lines (Fig. 9A). RQ suppressed the MMP-9 activity seen in the presence of menthol (Fig. 9A and $\mathrm{B})$.

\section{Discussion}

The oral cavity is readily influenced by environmental stimuli, such as heat and cold and taste sensation. Certain
TRP members have susceptibility to thermal changes and pungency, including TRPV1 (VR1; $>43^{\circ} \mathrm{C}$ and capsaicin), TRPM8 $\left(<25^{\circ} \mathrm{C}\right.$ and menthol), and TRPA1 (ANKTM1; $<17^{\circ} \mathrm{C}$ and mustard oil) $(6,7,21,22)$. The present PCR results demonstrated the existence of these mRNA in two oral SCC cell lines, HSC3 and HSC4. Menthol and another TRPM8 agonist, icilin, are known to stimulate other thermo-TRPs, such as TRPA1, while WS-12 has been shown not to alter the activities of other TRPs, such as TRPV1, TRPV2, TRPV3, TRPV4, and TRPA1 (10). In both HSC3 and HSC4 cells, we demonstrated the potent abilities of menthol and WS-12 to generate ionic currents, suggesting that TRPM8 channels are functional on the plasma membranes in these cells. One of the biophysical characteristics of TRPM8 channels is a 
A

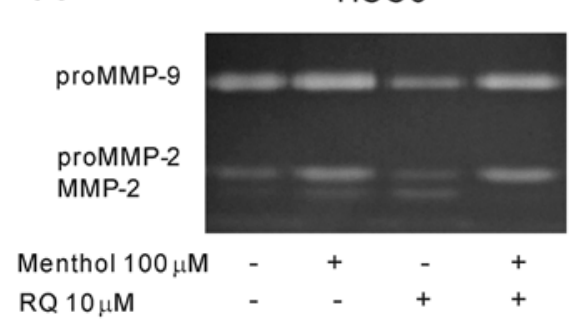

$\mathrm{HSC} 4$

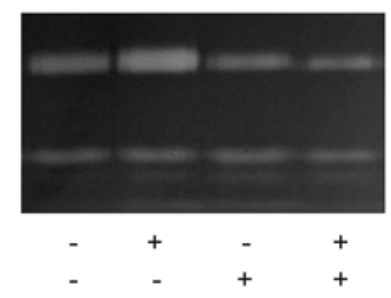

\section{B}

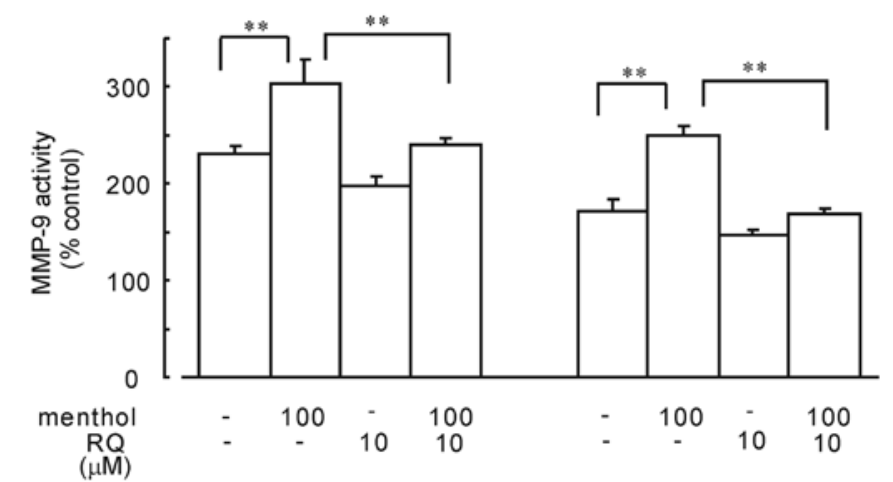

Figure 9. Gelatin zymography. Conditioned medium was collected from HSC 3 and HSC4 cells treated at $37^{\circ} \mathrm{C}$ for $24 \mathrm{~h}$ with menthol, RQ, a combination of the two, or vehicle. Panels show representative images (A) and summarized data (B). For the densitometric analysis of MMP-9 activity, each value is expressed as a percentage of the control value obtained in the absence of EGF. ${ }^{* *} \mathrm{p}<0.01$.

rapid, voltage-dependent closure at negative voltages, causing a strong outward rectification $(16,23)$. The modest rectification observed in the present study is likely to reflect their intrinsic voltage-dependent gating behavior reported to be indicated by the menthol-induced shift in activation curves toward negative membrane potentials (16). The published values for the relative $\mathrm{Ca}^{2+}$ permeability ratio of TRPM8 channels are quite discrepant: 3.3 (6) and 0.97 (7). Our estimated ratio (4.66) is close to the published values for TRPM8, but not to that reported for TRPV1 (9.60) (21), supporting the involvement of TRPM8 in menthol-induced currents in the present oral cancer cell lines.

Comparable amounts of TRPM8 mRNA were detected between HSC3 and HSC4 cells in our real-time PCR study. However, in the patch-clamp study menthol-sensitive cells were fewer among HSC3 than among HSC4 cells, in accordance with our finding that the protein displayed a more profound localization to the plasma membrane in HSC4 than in HSC3 cells. We made the noteworthy findings of an intracellular localization of TRPM8 and menthol-induced $\mathrm{Ca}^{2+}$-release in both HSC3 and HSC4 cells. TRPM8 expression has been reported in the ER membrane of the prostate cancer cell line LNCaP $(18,19)$. Of note, TRPM8 channels located in the ER of prostate cancer cell lines have been shown to be truncated isoforms that are distinct from the full-length TRPM8 present at the plasma membrane (24).

Recently, RQ was shown to be a specific TRPM8 antagonist, with the lowest degree of overlapping blocking action against TRP channels (11). The present study clearly demonstrates that RQ has a potent inhibitory effect on TRPM8-mediated responses associated with both the plasma membrane and ER channels, and this conclusion is strengthened by the findings that RQ strongly attenuated: i) menthol-activated and WS-12activated non-specific cation currents, ii) the current evoked by cold stimulation below the thermal threshold for TRPM8 (6), iii) menthol-induced $\mathrm{Ca}^{2+}$ release through intracellular TRPM8 channels followed by store-operated $\mathrm{Ca}^{2+}$ entry, the latter probably, at least in part, through TRMP8 channels on the plasma membrane, and iv) the basal $\left[\mathrm{Ca}^{2+}\right]_{\mathrm{i}}$, probably by reducing constitutive activity in TRPM 8 channels. These findings confirmed the distinct functions of the TRPM8 channels present in different subcellular regions in SCC cell lines.

Stimulation with menthol has been shown to increase both the intracellular $\mathrm{Ca}^{2+}$ level and cell migration in human glioblastoma cells $(25,26)$. The present results demonstrated that in the two HSC cell lines, menthol augmented motility, while RQ inhibited it through blockade of menthol-induced and constitutive TRPM8 activities, although neither of these agents had any effect on cell proliferation. Invasion across the basement membrane is a crucial step in the metastasis of tumor cells. An important finding made in the present study was that menthol accelerated the invasion of oral SCC cells, whereas RQ suppressed it by blocking menthol-induced and constitutive TRPM8 activities, suggesting that TRPM8 is involved in degrading ECM components. Invasive cells are reported to secrete proteolytic enzymes known as MMPs, such as MMP-2 and MMP-9, that degrade the basement membrane, which is mainly made up of type IV collagen $(27,28)$. Elevated $\left[\mathrm{Ca}^{2+}\right]_{\mathrm{i}}$ is likely to be involved in the above mechanism since the constitutive activity of TRPV2, another TRP channel, reportedly increases the intracellular $\mathrm{Ca}^{2+}$ level and promotes prostate cancer-cell invasion through MMP-9 activation (29). The present finding that menthol increases the gelatinase activity of MMP-9 while RQ suppresses it suggests that TRPM8-stimulation positively regulates MMP-9 activity, an inference in line with the TRPM8induced increase in metastatic potential. 
In conclusion, taken as a whole our results, obtained using a selective agonist and selective antagonist, clearly demonstrate that TRPM8 channels are expressed on the plasma membrane and/or in the intracellular region in the oral SCC lines, and that the agonist-induced and constitutive activities of TRPM8 channels are likely to be positively involved in the cell-invasion process via this channel's ability to increase MMP-9 activity. A TRPM8 antagonist has been reported to be effective for the treatment of bladder pain (30), and potent and selective TRPM8 antagonists have been supported as potential candidates for the treatment of neuropathic pain $(11,31)$. The present study is the first to provide evidence for a pathophysiological involvement of TRPM8 channels in the tumor cell invasion process. This potentially adds a new role to the therapeutic repertoire of TRPM8 antagonists (such as RQ): namely, acting on TRPM8 channels located at different subcellular sites, making them potential targets in the management of those oral SCC that are associated with a poor prognosis.

\section{Acknowledgements}

We thank Drs Kazuhiko Okamura, Kenichi Kato, Ryuji Uchida, and Mitsutoki Hatta for helpful discussion. This work was supported by a grant-in-aid for Scientific Research from the Japan Society for the Promotion of Science (17591958, 18059032) (T.O., T.I., J.Y.).

\section{References}

1. Byers RM, El-Naggar AK, Lee YY, Rao B, Fornage B, Terry NH, Sample D, Hankins P, Smith TL and Wolf PJ: Can we detect or predict the presence of occult nodal metastases in patients with squamous carcinoma of the oral tongue? Head Neck 20: 138-144, 1998.

2. Prevarskaya N, Zhang L and Barritt G: TRP channels in cancer. Biochem Biophys Acta 1772: 937-946, 2007.

3. Bödding M: TRP proteins and cancer. Cellular Signal 19: 617-624, 2007.

4. Venkatachalam K and Montell C: TRP channels. Ann Rev Biochem 76: 387-417, 2007.

5. Marincsák R, Tóth BI, Czifra G, Márton I, Rédl P, Tar I, Tóth L, Kovács and Bíró T: Increased expression of TRPV1 in squamous cell carcinoma of the human tongue. Oral Dis 15 : 328-335, 2009.

6. Mckemy DD, Neuhausser WM and Julius D: Identification of a cold receptor reveals a general role for TRP channels in thermosensation. Nature 416: 52-58, 2002.

7. Peier AM, Moqrich A, Hergarden AC, Reeve AJ, Andersson DA, Story GM, Earley TJ, Dragoni I, McIntyre P, Bevan S and Patapoutian A: TRP channel that senses cold stimuli and menthol. Cell 108: 705-715, 2002.

8. Tsavaler L, Shapero MH, Morkowski S and Laus R: Trp-p8, a novel prostate-specific gene, is up-regulated in prostate cancer and other malignancies and shares high homology with transient receptor potential calcium channel proteins. Cancer Res 61: 3760-3769, 2001

9. Henshall SM, Afar DE, Hiller J, Horvath LG, Quinn DI, Rasiah KK, Gish K, Willhite D, Kench JG, Gardiner-Garden M, et al: Survival analysis of genome-wide gene expression profiles of prostate cancers identifies new prognostic targets of disease relapse. Cancer Res 63: 4196-4203, 2003.

10. Sherkheli MA, Vogt-Eisele AK, Bura D, Márques LRB, Gisselmann $\mathrm{G}$ and Hatt $\mathrm{H}$ : Characterization of selective TRPM8 ligands and their structure activity response (S.A.R) relationship. J Pharm Pharm Sci 13: 242-253, 2010.

11. Watanabe $\mathrm{S}$, Ohmi $\mathrm{M}$, Inoue $\mathrm{T}$, Nonomura $\mathrm{C}$ and Fujiuchi $\mathrm{A}$ : Identification of novel TRPM8 channel antagonists. Program No. 73.7. 2009. Neuroscience Meeting Planner. Chicago, IL: Society for Neuroscience, 2009. Online.
12. Hamill OP, Marty A, Neher E, Sakmann B and Sigworth FJ: Improved patch-clamp techniques for high-resolution current recording from cells and cell-free membrane patches. Pflugers Arch 391: 85-100, 1981.

13. Grynkiewicz G, Poenie M and Tsien RY: A new generation of $\mathrm{Ca}^{2+}$ indicators with greatly improved fluorescence properties. $\mathrm{J}$ Biol Chem 260: 3440-3450, 1985.

14. Ohnishi Y, Lieger O, Attygalla M, Iizuka T and Kakudo K: Effects of epidermal growth factor on the invasion activity of the oral cancer cell lines HSC3 and SAS. Oral Oncol 44: 1155-1159, 2008.

15. Bernhard EJ and Muschel RJ: Ras, metastasis and matrix metalloproteinase 9. Cytoplasmic and nuclear signaling analysis. In: Methods Enzymol. Balch WE, Der CJ and Hall A (eds). Vol. 333. Academic Press, San Diego, pp96-104, 2001.

16. Voets T, Droogmans G, Wissenbach U, Janssens A, Flockerzi V and Nilius B: The principle of temperature-dependent gating in cold- and heat-sensitive TRP channels. Nature 430: 748-754, 2004.

17. Kühn FJP, Kühn C and Lückhoff A: Inhibition of TRPM8 by icilin distinct from desensitization induced by menthol and menthol derivatives. J Biol Chem 284: 4102-4111, 2009.

18. Zhang L and Barritt GJ: Evidence that TRPM8 is an androgendependent $\mathrm{Ca}^{2+}$ channel required for the survival of prostate cancer cells. Cancer Res 64: 8365-8373, 2004.

19. Thebault S, Lemonnier L, Bidaux G, Flourakis M, Bavencoffe A, Gordienko D, Roudbaraki M, Delcourt P, Panchin Y, Shuba Y, et al: Novel role of cold/menthol-sensitive transient receptor potential melastatine family member 8 (TRPM8) in the activation of store-operated channels in $\mathrm{LNCaP}$ human prostate cancer epithelial cells. J Biol Chem 280: 39423-39435, 2005.

20. Valero M, Morenilla-Palao C, Belmonte C and Viana F: Pharmacological and functional properties of TRPM8 channels in prostate cancer cells. Pflugers Arch 461: 99-114, 2011.

21. Caterina MJ, Schumacher MA, Tominaga M, Rosen TA, Levine JD and Julius D: The capsaicin receptor: a heat-activated ion channel in the pain pathway. Nature 389: 816-824, 1997.

22. Jordt SE, Bautista DM, Chuang HH, McKemy DD, Zygmunt PM, Högestätt ED, Meng ID and Julius D: Mustard oils and cannabinoids excite sensory nerve fibres through the TRP channel ANKTM1. Nature 427: 260-265, 2004.

23. Weil A, Moore SE, Waite NJ, Randall A and Gunthorpe MJ: Conservation of functional and pharmacological properties in the distantly related temperature sensors TRPV1 and TRPM8. J Pharmacol Exp Ther 68: 518-527, 2005.

24. Bidaux G, Flourakis M, Thebault S, Zholos A, Beck B, Gkika D, Roudbaraki M, Bonnal JL, Mauroy B, Shuba Y, et al: Prostate cell differentiation status determines transient receptor potential melastatin member 8 channel subcellular localization and function. J Clin Invest 117: 1647-1657, 2007.

25. Wondergem R, Ecay TW, Mahieu F, Owsianik G and Nilius B: $\mathrm{HGF} / \mathrm{SF}$ and menthol increase human glioblastoma cell calcium and migration. Biochem Biophys Res Commun 372: 210-215, 2008.

26. Wondergem R and Bartley JW: Menthol increases human glioblastoma intracellular $\mathrm{Ca}^{2+}, \mathrm{BK}$ channel activity and cell migration. J Biomed Sci 16: 90, 2009.

27. Hong SD, Hong SP, Lee JI and Lim CY: Expression of matrix metalloproteinase-2 and -9 in oral squamous cell carcinomas with regard to the metastatic potential. Oral Oncol 36: 207-213, 2000.

28. de Vicente JC, Fresno MF, Villalain L, Vega JA and Hernández Vallejo G: Expression and clinical significance of matrix metalloproteinase-2 and matrix metalloproteinase- 9 in oral squamous cell carcinoma. Oral Oncol 41: 283-293, 2005.

29. Monet M, Lehen'kyi V, Gackiere F, Firlej V, Vandenberghe M, Roudbaraki M, Gkika D, Pourtier A, Bidaux G, Slomianny C, et al: Role of cationic channel TRPV2 in promoting prostate cancer migration and progression to androgen resistance. Cancer Res 70; 1225-1235, 2010.

30. Lashinger ES, Steiginga MS, Hieble JP, Leon LA, Gardner SD, Nagilla R, Davenport EA, Hoffman BE, Laping NJ and Su X: AMTB, a TRPM8 channel blocker: evidence in rats for activity in overactive bladder and painful bladder syndrome. Am J Physiol Renal Physiol 295: F803-F810, 2008.

31. Al-Shamahi A,Kirkham K and Hookes L: Society for Neuroscience - 39th Annual Meeting. Part 1 - Novel therapies for the treatment of CNS disorders and pain. IDrugs. 12: 731-733, 2009. 